\title{
Economic Development Strategy: An Analysis of Leading Sector in Disadvantaged Regions of Pesisir Barat Regency
}

\author{
Feri Hardani $^{1 凶}{ }^{\text {, Toto Gunarto }}{ }^{2}$, Neli Aida ${ }^{3}$ Yudastio $^{4}$ \\ ${ }^{123}$ Magister Science of Economics, University of Lampung, Lampung, Indoneisa \\ ${ }^{4}$ Economics Faculty, University of Saburai, Lampung, Indoneisa \\ 凶ferihardani@gmail.com
}

\section{Received: \\ 21 September \\ 2021 \\ Revised: \\ 6 Ocotber 2021 \\ Accepted: \\ 6 October 2021 \\ Published: \\ 6 October 2021}

\begin{abstract}
Pesisir Barat Regency is the youngest regency in Lampung Province. Pesisir Barat Regency is the result of the division of West Lampung Regency, which was ratified based on Law Number 22 of 2012 concerning the Establishment of the West Coast Regency of Lampung Province on October 25, 2012 then inaugurated on April 22, 2013. West as an underdeveloped district in Indonesia, As a new autonomous region, West Coast District continues to improve to catch up, align itself or even surpass other areas in Lampung Province. Efforts to improve are carried out in a synergistic and simultaneous manner covering all fields and sectors, both in the government, economic, and cultural sectors. These efforts lead to the goal of prospering the people of Pesisir Barat Regency. West coast district has a lot of regional potential that can be developed to improve the status of the area and carry out development for progress. This study aims to look at the leading sectors in the disadvantaged areas of the west coast district. Based on the results of the analysis and calculation results that have been carried out, there are several leading sectors in the west coast district, namely the Location Question> 1. Shortly, the west coast district as a disadvantaged district has the potential to be developed based on its superior sector.
\end{abstract}

Keywords: Economic development; Underdeveloped regions; Leading Sector.

\section{INTRODUCTION}

The leading sector is the most effective sector to act as an engine of development in the context of realizing sustainable regional development goals which refers to the ability of the sector to encourage and support the growth and development of all economic sectors.

The leading sector as a very important sector in the economic development of a region does not only refer to its geographical location but is a sector that spreads in various economic channels so that it is able to move the economy as a whole. The characteristics of sectors that have advantages are as follows:

1. This sector has a high rate of economic growth

2. This sector has a relatively large distribution of labor

3. This sector has high inter-sector linkages, both forward and backward linkages

4. The sector is able to create high added value. 
Pesisir Barat Regency has an agricultural sector which is still one of the main pillars for regional development and is expected to make a major contribution to the GRDP of Pesisir Barat Regency. Support for the agricultural sector to GRDP is achieved through increased production of food crops and horticulture.

According to the Presidential Regulation, the government determines underdeveloped regions every five years nationally based on criteria, indicators, and sub-indicators of regional underdevelopment. The determination of underdeveloped areas as referred to is carried out based on the proposal of the minister by involving the relevant ministries/institutions and the regional government. In the event of the formation, expansion, and merger of regencies or efforts to overcome extraordinary circumstances, conflict situations, or natural disasters, according to this Presidential Regulation, the president can determine new underdeveloped areas. Presidential Regulation Number 63 of 2020 concerning the Determination of Disadvantaged Regions for 2020 - 2024 states that the west coast district is an underdeveloped district in Lampung Province. From Presidential Regulation (henceforth Perpres) No. 63 of 2020, apart from the Pesisir Barat Regency.

The factors that form the basis for determining disadvantaged areas are the community's economy, human resources, facilities and infrastructure, regional financial capacity, accessibility; and regional characteristics. Based on this, the author considers it necessary to conduct research on the leading sector in the west coast district as an economic development strategy, because it will answer the indicators of underdeveloped areas about the community's economy, and the characteristics of the west coast district.

Research conducted by Almasdi Syahza (2013) on the Development Model of Disadvantaged Regions in Efforts to Accelerate Rural Economic Development. Using a descriptive method analysis, it shows that the strategy for the direction of development is to strengthen the function of the Meranti Islands Regency in the fields of agriculture, plantation infrastructure, tourism, human resource development. . This study also found a model for reducing the number of poor families by referring to the four principles of strategies for reducing the number of poor families.

Research conducted by Happy Okysari (2015) on Development of Disadvantaged Areas in Klaten Regency. Using the Rapid Rural Appraisal Method, in-depth interviews and SWOT analysis methods. Shows that the underdeveloped village development strategy adapts to the potential and problems that exist in each underdeveloped village according to their respective typology. Determination of underdeveloped villages with indicators of village potential, housing and the environment, population conditions, and rural areas.

Research conducted by Iqbal M. Mujtahid (2015) on the Regional Development Strategy of Bengkulu Province, Indonesia Towards the 2015 MDGs using a descriptive/qualitative using an interactive model shows that strategic issues agreed to be developed together are tourism development, trade and industry, agriculture and plantations, human resources and employment.

Research conducted by Erlin Agustin in 2020 on the analysis of development strategies for underdeveloped areas as an effort to accelerate economic development In the West Coast District, using a SWOT analysis, shows that the main strength of Pesisir Barat Regency is an area with great potential as tourism, the main weakness of Pesisir 
Barat Regency shown by the strategic factors of community poverty, the main opportunity for the Pesisir Barat Regency is the rapid development of technology, the main threat from the Pesisir Barat Regency is prone to natural disasters, the priority strategy is to utilize the development of information technology to increase tourism in the Pesisir Regency. West.

Based on research conducted by Erlin Agustin, it can be refined by adding calculations related to which sectors are the leading sectors, because the research has shown development strategies, but the leading sectors in the West Coast District are still not visible. So that through this research it will be answered whether the west coast district as an underdeveloped area has a leading sector, and whether the sector is the leading sector in the west coast district.

\section{METHOD}

This research was conducted at Madrasah Ibtidaiyah Nu Sumber Agung, whose address is at J1. Depati Agung Desa Sumber Agung, Buay Madang, Oku Timur, Indonesia. This study uses a quantitative approach, namely research activities by prioritizing data collection in the form of numbers, then the numbers are analyzed using two-way Annava.

Method is a way of working that can be used to get something. While the research method can be interpreted as a procedure for working in the research process, both in searching for data or in disclosing existing phenomena (Zulkarnaen, W., et al., 2020). This study uses secondary data collected through the Central Statistics Agency.

Quantitative approach that can be used to identify the potential of an area is to use location quotient (lq) analysis and shift share analysis. LQ is a comparison between the role of an economic sector in an area to the magnitude of the role of the same economic sector nationally or a comparison to an area that has a larger administrative scope (Tarigan, 2014).

LQ is used to see the sectorial advantages of an area with other regions or study areas with reference areas. This analytical tool is used to determine the base and nonbase sectors in a region. LQ analysis is done by comparing the distribution of the percentage of each sector in each district or city with the province. (Lincolin Arsyad, 1999). The way to calculate LQ is:

Where:

$$
L q=\frac{X i r}{X r}: \frac{X i n}{X n}
$$

1. Xir is a sector $\mathrm{i}$ at the regional level

2. $\mathrm{Xr}$ is the sum of all sectors at the regional level

3. Xin is a sector $i$ at the national level

4. $\mathrm{Xn}$ is the sum of all sectors at the national level

The results of the LQ calculation can be interpreted as follows:

1. LQ $>1$, indicating that product exports are carried out in the sector, exports are carried out because there is a surplus. (the role of the sector is greater at the local level than at the national level) 
2. LQ $<1$, indicates that the sector needs to import because the sector has not been able to meet regional needs. (the role of the sector is smaller at the local level than at the national level)

3. $\mathrm{LQ}=1$, indicating that there is a balanced productivity which means this sector is still not suitable for export. (the role of the sector is the same both regionally and nationally)

\section{FINDINGS AND DISCUSSION}

Based on the results of calculations using GRDP data for Pesisir Barat Regency ADHK 2010 and GRDP Lampung Province ADHK 2010, related to business fields during the last 8 years (2013-2020) it can be seen that there are 8 (eight) economic sectors in Pesisir Barat Regency with an LQ value $>1$ or is the base sector.

In detail, the LQ value of Pesisir Barat Regency in 2013-2020 is presented in the following table.

Table 1. LQ Value of Pesisir Barat Regency 2013-2020

\begin{tabular}{|c|c|c|c|c|c|c|c|c|c|c|}
\hline & Business field & 2013 & 2014 & 2015 & 2016 & 2017 & 2018 & 2019 & 2020 & Average \\
\hline $\mathbf{A}$ & $\begin{array}{l}\text { Agriculture, } \\
\text { Forestry and } \\
\text { Fisheries }\end{array}$ & 1.61 & 1.62 & 1.64 & 1.66 & 1.68 & 1.72 & 1.75 & 1.76 & 1.68 \\
\hline B & $\begin{array}{l}\text { Mining and } \\
\text { excavation }\end{array}$ & 0.77 & 0.75 & 0.79 & 0.84 & 0.85 & 0.88 & 0.93 & 0.96 & 0.85 \\
\hline $\mathrm{C}$ & $\begin{array}{l}\text { Processing } \\
\text { industry }\end{array}$ & 0.31 & 0.30 & 0.30 & 0.30 & 0.30 & 0.29 & 0.27 & 0.24 & 0.29 \\
\hline D & $\begin{array}{l}\text { Electricity and } \\
\text { Gas Supply }\end{array}$ & 0.06 & 0.06 & 0.07 & 0.09 & 0.09 & 0.08 & 0.09 & 0.11 & 0.08 \\
\hline $\mathbf{E}$ & $\begin{array}{l}\text { Water Supply, } \\
\text { Waste } \\
\text { Management, } \\
\text { Waste and } \\
\text { Recycling }\end{array}$ & 0.52 & 0.54 & 0.54 & 0.52 & 0.51 & 0.47 & 0.48 & 0.47 & 0.51 \\
\hline $\mathbf{F}$ & Construction & 0.55 & 0.56 & 0.54 & 0.54 & 0.57 & 0.58 & 0.61 & 0.74 & 0.58 \\
\hline $\mathbf{G}$ & $\begin{array}{l}\text { Wholesale and } \\
\text { Retail Trade; } \\
\text { Car and } \\
\text { Motorcycle } \\
\text { Repair }\end{array}$ & 1.02 & 1.06 & 1.04 & 1.04 & 1.00 & 1.00 & 1.01 & 1.03 & 1.02 \\
\hline $\mathbf{H}$ & $\begin{array}{l}\text { Transportation } \\
\text { and } \\
\text { Warehousing }\end{array}$ & 0.19 & 0.19 & 0.20 & 0.20 & 0.20 & 0.20 & 0.20 & 0.20 & 0.20 \\
\hline I & $\begin{array}{l}\text { Provision of } \\
\text { Accommodatio } \\
\mathrm{n} \text { and Food and } \\
\text { Drink }\end{array}$ & 1.02 & 1.06 & 1.08 & 1.10 & 1.08 & 1.10 & 1.09 & 1.10 & 1.08 \\
\hline $\mathbf{J}$ & $\begin{array}{l}\text { Information and } \\
\text { Communication }\end{array}$ & 0.48 & 0.47 & 0.47 & 0.46 & 0.48 & 0.49 & 0.49 & 0.48 & 0.48 \\
\hline $\mathbf{K}$ & $\begin{array}{l}\text { Financial } \\
\text { Services and } \\
\text { Insurance }\end{array}$ & 0.75 & 0.73 & 0.74 & 0.72 & 0.70 & 0.69 & 0.69 & 0.69 & 0.71 \\
\hline $\mathbf{L}$ & Real Estate & 1.28 & 1.26 & 1.25 & 1.27 & 1.24 & 1.26 & 1.28 & 1.29 & 1.27 \\
\hline
\end{tabular}




\begin{tabular}{|c|c|c|c|c|c|c|c|c|c|c|}
\hline & Business field & 2013 & 2014 & 2015 & 2016 & 2017 & 2018 & 2019 & 2020 & Average \\
\hline $\begin{array}{l}\mathbf{M} \\
\mathbf{N}\end{array}$ & $\begin{array}{l}\text { Company } \\
\text { Services }\end{array}$ & 0.90 & 0.91 & 0.96 & 0.96 & 0.95 & 0.95 & 0.97 & 1.01 & 0.95 \\
\hline $\mathbf{O}$ & $\begin{array}{l}\text { Government } \\
\text { Administration, } \\
\text { Defense and } \\
\text { Mandatory } \\
\text { Social Security }\end{array}$ & 1.45 & 1.47 & 1.44 & 1.39 & 1.44 & 1.47 & 1.51 & 1.51 & 1.46 \\
\hline $\mathbf{P}$ & $\begin{array}{l}\text { Education } \\
\text { Services }\end{array}$ & 1.23 & 1.27 & 1.27 & 1.27 & 1.24 & 1.24 & 1.23 & 1.23 & 1.25 \\
\hline $\mathbf{Q}$ & $\begin{array}{l}\text { Health Services } \\
\text { and Social } \\
\text { Activities }\end{array}$ & 1.06 & 1.07 & 1.10 & 1.11 & 1.11 & 1.11 & 1.13 & 1.15 & 1.11 \\
\hline $\begin{array}{l}\mathbf{R}, \\
\mathbf{S}, \\
\mathrm{T}, \\
\mathrm{U}\end{array}$ & Other services & 1.16 & 1.17 & 1.13 & 1.13 & 1.11 & 1.15 & 1.15 & 1.15 & 1.14 \\
\hline
\end{tabular}

Source of analysis results 2021

Based on the results of the analysis above, it shows that the west coast district has a leading sector from the province of Lampung, which is the leading sector isAgriculture, Forestry, and Fisheries Sector; Wholesale and Retail Trade; Car and Motorcycle Repair; Provision of Accommodation and Food and Drink; Real Estate; Government Administration, Defense and Mandatory Social Security; Education Services; Health Services and Social Activities; Other services.Meanwhile, the other 10 (ten) sectors are non-base sectors with an LQ value $<1$.

Research conducted by Erlin Agusta on the analysis of development strategies for underdeveloped areas as an effort to accelerate economic development in the west coast district in 2020 shows that the west coast development strategy can be carried out with tourism development because the tourism sector is the leading sector in the west coast district, based on research and calculations carried out by Erlin Agusta. has been carried out, there are several other sectors that are superior in the west coast district such as Agriculture, Forestry, and Fisheries Sector; Wholesale and Retail Trade; Car and Motorcycle Repair; Provision of Accommodation and Food and Drink; Real Estate; Government Administration, Defense and Mandatory Social Security; Education Services; Health Services and Social Activities; Other services. With a value of $L Q>1$. This research still has shortcomings because it is only limited to the use of simple analytical tools. For further researchers in the context of developing research and deepening research, other methods and analytical tools can be added.

\section{CONCLUSION}

Based on the research conducted, there are 8 leading sectors in underdeveloped areas of the west coast district, namely: Agriculture, Forestry, and Fisheries Sector; Wholesale and Retail Trade; Car and Motorcycle Repair; Provision of Accommodation and Food and Drink; Real Estate; Government Administration, Defense and Mandatory Social Security; Education Services; Health Services and Social Activities; Other 
services. With a value of $L Q>1$. Based on this, the west coast district as a disadvantaged district has the potential to be developed based on its superior sector, in line with previous research conducted by Erlin Agusta in 2020 the tourism sector entered the accommodation and food and drink sector as the leading sector in the west coast district.

\section{ACKNOWLEDGMENTS}

Thanks to Professor Toto Gunarto, SE, M.Si, and also to Dr. Neli Aida, SE, M.Si, for the help and guidance in the process of completing this paper, I hope this article can be useful for readers, and increase knowledge.

\section{REFERENCES}

Arsyad, Lincoln, 2004, Development Economics, Fourth Edition, STIE YKPN, Yogyakarta

Bendavid-Val, Avron, 1991, Regional and Local Economic Analysis for Practitioners, Four Edition Sage Publication Inc., California, USA.

Blakely, Edward J and Bradshaw, 2002, Planning local Economic Development: Theory and Practice, Third Edition, Sage Publications, California, USA.

Boediono, 1999, Economic Growth Theory, First Edition, BPFE Publisher, Yogyakarta

Central Bureau of Statistics Indonesia, Statistics Indonesia 2020, BPS Statistics Indonesia

Central Bureau of Statistics of Lampung Province, Statistics of Lampung Province 2020, BPS Statistics Indonesia

Hanham, RQ, and Shawn, B., 2000, Shift-Share Analysis and Change in Japanese Manufacturing Employment, Growth and Change, Vol. 31, 108-123.

Hassan, Mohd Khairul Hisham, Zakariah Abdul Rashid, Khalil AbdulHamid (2011), East Coast Economic Region From The Perspective of Shift-Share Analysis, International Journal of Business and Society, Vol. 12, No. 1, 2011, 79-88.

Kuncoro, M., 2004, Autonomy and Regional Development: Reform, Planning, Strategy, and Opportunity, Erlangga Publisher, Jakarta.

Munir, Badrul, 2002, Regional Development Planning in the Perspective of Regional Autonomy, First Edition, Bappeda of West Nusa Tenggara Province, Mataram.

National Mid-Term Development Plan 2020-2024

Nelson, C., Arthur, William, P., Drumond, and David., Sawicki, 1994, Economic Base : Analysis of Employment Trends by Economic Sector, Economic Development Review, Summer, 32-36.

Putra, MF, (2011), Study of Public Policy and Governance in Perspective Quantitative, Universitas Brawijaya (UB) Press, First Issue, April 2011, Malang. Regional Development Planning Agency of Tanggamus Regency Government

Rex, TR, 1997, Key Arizona Economic Activities Identified, Arizona State University, Monthly Newsletter on The Arizona Economic, Vol. IV, No. 9, 1-6.

Richardson, Harry, 1977, Fundamentals of Regional Economics, translation by Paul Sihotang, Faculty of Economics, University of Indonesia, Jakarta.

Sjafrizal, 2008, Regional Economics: Theory and Application, Baduose Media, Padang. Soepono, Prasetyo, 1993, Shift-Share Analysis of Development and Application, Journal of Economics and Business, No. 1 Year III: 43-54.

Sukirno, Sadono, 2007, Modern Macroeconomics The Development of Thought From Classical to New Keynesian PT. Raja Grafindo Persada, Jakarta 
Sukirno, Sadono, 2011, Development Economics: Processes, Problems, and Policy Basis, Publishing Institute, Faculty of Economics UI and Bina Graphics, Jakarta.

Tambunan, Tulus TH, 2003, Indonesian Economy, Ghalia Indonesia, Jakarta

Tarigan, Robinson, 2007, Regional Economic Theory and Application, PT Bumi Aksara, Jakarta.

Todaro, MP, 2000, Economic Development in the Third World, Seventh Edition, Translated by Harris Munandar, Airlangga Publisher, Jakarta.

Widodo, Tri, 2006, Development Planning: Computer Applications (Regional Autonomy Era), UPP STIM YKPN Publisher, Yogyakarta.

Wijaya, A. 1996. Economics Journal of Industrial Development Options: The Case of DKI Jakarta, No IV (2), Jakarta.

Yeo, Benjamin JK, 2010, Driving the Knowledge Economy : Explaining the Impact of Regional Innovation Capacity on Economic Performance, Contemporary Management Research Pages 71-86, Vol. 6, No. 1, March 2010.

Yusuf, Maulana, 1999, Growth Ratio Model (MRP) as an Alternative Analysis Tool in Urban and Regional Planning, Model Application: Bangka Belitung, Economics and Indonesian Finance, Vol. XLVII, No. 2: 221-233. 